\title{
セルラーゼの結晶セルロース加水分解反応を利用した セロビオースの効率的連続生産
}

\author{
田中三男 ${ }^{\dagger+} \cdot$ 藤本 篤・三井亮司
}

\author{
岡山理科大学理学部 生物化学科, 700-0005 岡山市理大町 1-1
}

Trichoderma viride 起源のセルラーゼ標品より 1 段階のカラムクロマトグラフィーで, ほぼ完全に $\beta$ -glucosidase 活性の除去されたセルラーゼ活性画分（PEAK I）が得られた. PEAK I を MCC の連続加 水分解実験に供した. PEAK I $(3.0 \mathrm{~g} / l)$ を槽内に保持できる反応槽内へ, MCC 懸濁液 $(55.0 \mathrm{~g} / l)$ を連 続的に供給 (12.8mg MCC/h) しながら, MCC の加水分解を行った。关の結果, 反応 168〜576 時間の間 で定常状態が得られ，セロビオース濃度は約 3.5 3.0 $\mathrm{g} / l$, セロビオース含有率は $75 \%$, およびセロビオ

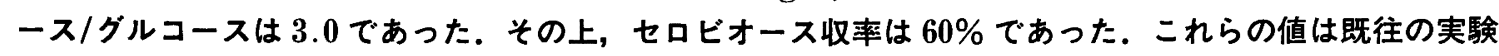
值と比較して,いずれも相当に高い值であった. 本実験における MCC の連続加水分解系は生成物が連続的 に反応槽外に取り出されるのでセロビオースのグルコースへの分解が抑えられること，および，反応中の 酵素の失活がほとんどないので, 酵素の損失が少ないことなどの利点を有する.

\section{緒言}

機能性食品の一種であるオリゴ糖は低カロリーであり虫歯子防, 抗菌性, 抗腫瘍性, ビフィズス菌増殖作用, コレステロール蓄積 防止能など優れた性質を持つものが多い(Sakai, 1995; Ishikura， 1992). 草木質資源から得られるセルロースの部分加水分解によっ て得られるセロビオ一スもオリゴ糖の一種であり，ビフィズス菌 増殖活性を持つ難分解性オリゴ糖として位置づけられている，草 木質中のセルロースは人間には消化できず，デンプンのように人 間の食糧としての競合は起らない。このようなセルロースを有効 に利用することは大量に廃棄処分されている農林産廃棄物の有効 利用になるばかりではなく，環境破壊防止の一助にもなり得る. このような観点からセルロースを大量処理し，有効に利用し得る 方法の一つとして酵素的加水分解によりセロビオース(オリゴ糖) を効率良く生産することが試みられている (Homma et al., 1993 ; Ina and Kinoshita, 1993 ; Ooshima et al., 1991 ; Taniguchi, 1989). セルロースの加水分解法には酸分解法と酵素分解法と があるが, 前者では反応副産物が多くなりセロビオースやグルコ 一スの収率が低下する. 一方, 後者では温和な反応条件で反応が 行え, 副反応がおこらないなどの利点がある. しかしながら, 粗 セルラーゼ䣼素は多成分系であり，多種の活性成分が混在してい る. その上, $\beta$-glucosidase 活性成分も含まれているために, 生産 されたセロビオースはグルコースにまで加水分解される。したが って， $\beta$-glucosidase 活性成分を除去した酵素系で加水分解を行 うのか望ましい (Ina and Kinoshita, 1993; Homma et al., 1993 ; Homma et al., 1992). しかしながら, 回分反応系ではセ ロビオースが蓄積するため生成物阻害が起こり酵素活性は徐々に 低下寸る。生成物阻害を抑制するためには，生成物を除去しなが ら反応の行える連続反応系が有利と考之られるが, 不溶性の基質 を連続的に供給しながら，生産効率について検討した例は見当た らない.

\footnotetext{
$\dagger 1999$ 年 9 月 17 日受理

化学工学会岡山大会（岡山、1997 年 7 月）にて発表

$\dagger \dagger$ mtanaka@dbc.ous.ac.jp
}

本研究では, セルロース懸濁液を連続的に限外沪過装置内に供 給しながら, 装置内に酵素を保持しつつ反応生成物のみを沪過す ることにより，セロビオースを効率良く生産することを目的とし て実験を行ったので報告する.

\section{1. 実験}

\section{1 醳素の部分精製}

Trichoderma viride 起源の粗酵素, Meicelase CEP-6000 (明治 製菓(株)製）を $\beta$-Glucosidase 活性除去のための部分精製に用い た. Meicelase CEP-6000 (4.0 g)に0.05 M 酢酸緩衝液 (pH 5.0) を $40 \mathrm{~m} l$ 加えた後, 一晚冷蔵庫中に放置して得られた拲濁液を遠 心分離 $\left(3000 \times \mathrm{g}, 15 \mathrm{~min}, 4^{\circ} \mathrm{C}\right)$ した. 得られた上澄みを限外沪 過膜 PM-10（アミコン社製；分画分子量 10,000 ）を装着した装 置（ダイアフローセル）中で，0.25 M 酢酸緩衝液（pH 4.5）を流 しながら洗浄透析とともに濃縮して, 粗酵素溶液を得た。

$0.25 \mathrm{M}$ 酶酸緩衝液（pH 4.5）で予め平衡化した Amberlite CG -50 (TYPE II， 200-400 mesh ; オルガノ(株)製) カラム $(2.4 \times$ $39 \mathrm{~cm})$ に上記粗酵素溶液 $(10 \mathrm{~m} l)$ を添加し, 酢酸緩衝液 $(0.25$ $\mathrm{M}(\mathrm{pH}$ 4.5)，0.30 M (pH 5.0)) を用いてステップワイズ法 (Okada and Tanaka, 1988) にて分画した $(10 \mathrm{ml} /$ fraction, 流 速は $1.0 \mathrm{ml} / \mathrm{min})$. 得られた画分は上記と同様に $0.05 \mathrm{M}$ 酷酸緩 衝液（pH 5.0）を流しながら洗净透析とともに浱縮した. 得られ た部分精製セルラーゼ成分のタンパク濃度, 微結晶セルロース (MCC) 分解活性, カルボキシメチルセルロース (CMC) 分解活 性, $\beta$-Glucosidase 活性（ $p$-ニトロフェニル- $\beta$-D-グルコピラ）

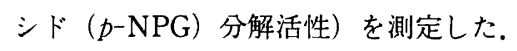

\section{2 部分精製セルラーゼ成分の各種基質に対する活性}

$1.2 .1 \mathrm{MCC}$ 分解活性 反応は $5.0 \mathrm{~m} l$ で行った. 反応瓶 $(8$ $\mathrm{m} l$ ) に MCC を $50.0 \mathrm{mg}$ 精科し， 0.05 M 酢酸緩衝液（pH 5.0） を添加し, $30^{\circ} \mathrm{C} て ゙ 24$ 時間振とうを行った. その後, 酵素溶液を添 加して反応を開始した $(10 \mathrm{~g} / l \mathrm{MCC}, 1.0 \mathrm{~g} / l$ 酵素). 反応開始直 後 (反応時間 0 時間目) と反応 24 時間目でサンプリング $(1.0 \mathrm{ml})$ を行い, 遠心分離 $\left(3,000 \mathrm{x} \mathrm{g}, 15 \mathrm{~min}, 4^{\circ} \mathrm{C}\right)$ して上澄みを回収 した.上澄み中の全糖濃度をフェノールー硫酸法により测定し, MCC 分解活性 (mg total sugar $/ \mathrm{g}$ protein/min) を求めた. 定量 
のための標準物質としてグルコースを用いた。

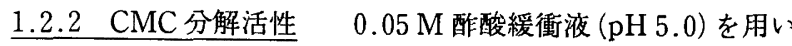

て $4.4 \mathrm{~g} / l$ の CMC 溶液を調製した。試験管中に CMC 溶液 $(5.0$ $\mathrm{m} l)$ を入れ, $30^{\circ} \mathrm{C} て ゙ 15$ 分間静置した。 その後, 適切な濃度に希 釈した酵素溶液 $(0.5 \mathrm{~m} l)$ を添加して反応を開始した. 反応 0 , $10,20,30$ 分目で反応溶液を $0.5 \mathrm{~m} l$ ずつ取りだし, 標線付試験管 中の $0.25 \mathrm{~N} \mathrm{NaOH}$ 水溶液 $(0.5 \mathrm{~m} l)$ 中に添加して反応を停止さ せた。 その後，還元糖濃度を Somogyi-Nelson 法により測定し， $\mathrm{CMC}$ 分解活性 (mg reducing sugar/g protein $/ \mathrm{min}$ ) を求めた。 定量のための標準物質としてグルコースを用いた.

\section{$1.2 .3 \beta$-Glucosidase 活性 $\quad 0.05 \mathrm{M}$ 酢酸緩衝液（pH 5.0）} を用いて, $0.3 \mathrm{~g} / l$ の $p-\mathrm{NPG}$ 溶液を調製した。試駼管中に $p$ $\mathrm{NPG}$ 溶液 $(2.0 \mathrm{~m} l)$ を入れ, $30^{\circ} \mathrm{C} て ゙ 15$ 分間静置した。適切な濃 度に希釈した酵素溶液 $(0.2 \mathrm{~m} l)$ を添加して反応を開始した。 反 応 $0,5,10,15$ 分目で各反応溶夜に $1 \mathrm{M}$ 炭酸ソーダ溶液(要時調 製)を $2.0 \mathrm{ml}$ ずつ添加して, 反応を停止させ発色させた. 生成し た $p$-nitrophenol（p-NP） 濃度を測定（波長 $400 \mathrm{~nm}$ での吸光度 を測定） L, $p$-NPG 分解活性, 即ち $\beta$-Glucosidase 活性 (mg $p$ -NP/g protein/min) を求めた。定量のための標準物質として $p$ 一N を用いた。

1.2 .4 セロビオースおよびグルコース量セロビオースお よびグルコース濃度の測定には高速液体クロマトグラフィー (HPLC，東ソー(株)製) を用いた。 カラムには TSK-gel Amide -80 (4.6 mm $\times 25 \mathrm{~mm} \times 2$ 本), 溶離液にはアセトニトリル：蒸留 水 $=75: 25(\mathrm{~V} / \mathrm{V}) \%$ を用い, 流速は $1.0 \mathrm{ml} / \mathrm{min}$, カラム温度は $80^{\circ} \mathrm{C}$ とし，検出は RI（示差屈折計）で行った.

1.2 .5 酵素タンパク量 牛血清アルブミンを標準物質とし て, Lowry-Folin 法により测定した.

\section{$1.3 \mathrm{MCC}$ 加水分解反応}

1.3 .1 回分反応 まず,最適なセロビオース生成反応条件を 決定するために, 酵素濃度を $1.0 \mathrm{~g} / l$ に固定し, 基質濃度を $10.0 \sim 50.0 \mathrm{~g} / l$ の間で変化させる場合と, 基質浱度を $20.0 \mathrm{~g} / l$ に 固定し, 酵素濃度を $1.0 \sim 10.0 \mathrm{~g} / l$ の間で変化させる場合の 2 通 クの実験を行った。反応溶液は $0.05 \mathrm{M}$ 酢酸緩衝液 (pH 5.0) とし

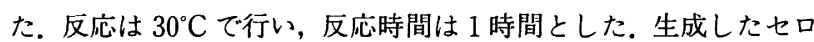
ビオース，グルコースおよび全糖の濃度を测定した。 反応上澄み 液中の酵素タンパク質を除去するため，セントリカット（倉敷紡 績社製）を用いて，遠心分離し，沪液を測定に用いた，次に，最 適条件でのセロビオース生成の経時変化を追跡した. 反応瓶 $(28$ $\mathrm{m} l$ ) に精科した $0.5 \mathrm{~g}$ MCC を入れ，0.05 M 酢酸紘衝液 (pH 5.0) を添加した. $30^{\circ} \mathrm{C} て ゙ 24$ 時間振とうした後, 酵素溶液を添加して反 応を開始した。酵素濃度および基質濃度はそれぞれ $3.0 \mathrm{~g} / l$ およ び $20.0 \mathrm{~g} / l$ である. 反応㲘濁液 $(1.0 \mathrm{~m} l)$ を経時的にサンプリン グし，遠心分離 $\left(3000 \mathrm{x} \mathrm{g}, 15 \mathrm{~min}, 4^{\circ} \mathrm{C}\right)$ した。 上澄み液を上記 のように処理をした後, 生成したセロビオース, グルコースおよ び全糖の濃度を測定した。

1.3.2 連続反応 Fig. 1 に連続反応装置の概略図を示した。 反応槽 (Reactor) には限外汇過膜 (PM-10, 分画分子量；10,000) を装備した限外沪過装置（アミコン社製）を用い，槽内の反応影 濁液量を $50 \mathrm{~m} l$ とした. 反応槽に液面コントローラー（Level gage, 光液面計 SA-107：藤原製作所(株)製)を取り付け, $0.1 \mathrm{M}$ 酢酸緩衝液（pH 4.5）で調製した MCC 愻濁液を供給するポン プ(S.P., FMI 定量ポンプQG 6；山善(株)製)と連動させ, Reactor 内の䇣濁液量が一定になるようにした．マイクロチューブポ

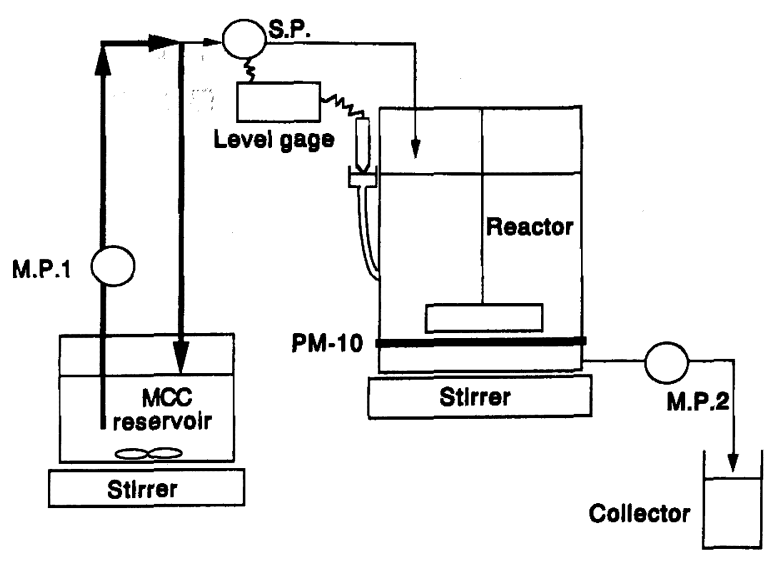

Fig. 1 Apparatus for continuous hydrolysis of MCC by supplying MCC suspension into reactor

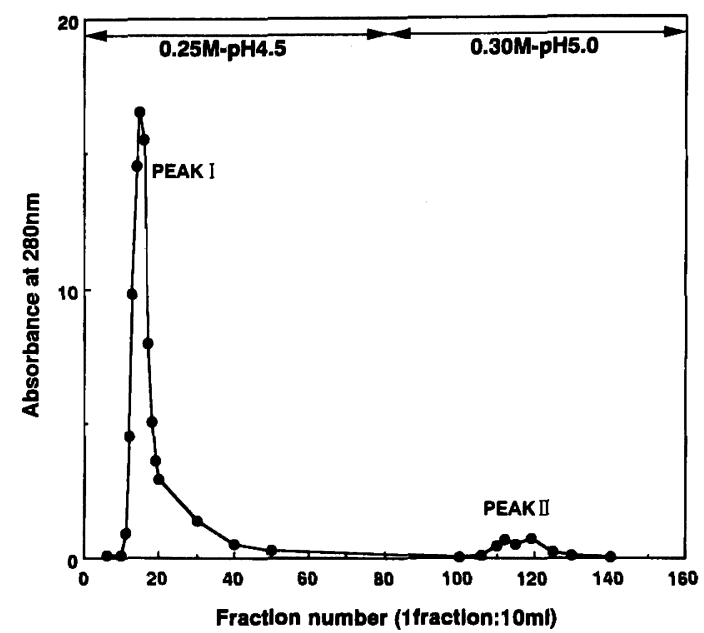

Fig. 2 Purification of crude Meicelase by Amberlite CG-50 (Type II) column. Elution buffers were $0.25 \mathrm{M}$ acetate buffer ( $\mathrm{pH} 4.5)$ and $0.30 \mathrm{M}$ acetate buffer ( $\mathrm{pH} 5.0)$

ンプ（M.P.1）により MCC 絜濁液を S.P. と MCC 瑟濁液貯留槽 (MCC reservoir) の間で高速循環させることにより MCC の沈殿 を防止した，上記緩衝液で調製した酵素液を Reactor 内に添加し て反応を開始した，反応は恒温室 $\left(28^{\circ} \mathrm{C}\right)$ でおこなった. Reactor 出口のマイクロチューブポンプ (M.P.2)により一定流速で排出さ れる反応溶液を回収瓶 (Collector) に回収するとともに，任意反 応時間での Reactor 中の反応溶液の各種糖濃度測定用として経 時的に少量の反応液をサンプリングした. 全排出液量はメスシリ ンダーにて測定した，MCC reservoir 中の MCC 照濁液としては， MCC と緩衝液を十分に馴染ませるため, 悲濁液調製後, 20 時間以 上経過したものを用いた。

Reactor 内の MCC 濃度を $50.0 \mathrm{~g} / l$, 酵素濃度を $3.0 \mathrm{~g} / l$ とし て反応を開始した. 上記緩衝液の $\mathrm{pH}$ を 4.5 としたのは, 予備実験 において本酵素の $\beta$-glucosidase 活性が若干抑制されることが確 かめられたことによる. 反応液の滞留時間は 21.5 時間とした.こ のとき MCCの供給速度は $12.8 \mathrm{mg} / \mathrm{h}$ であった（MCCreservoir 中の $\mathrm{MCC}$ 濃度は $55 \mathrm{~g} /($ である).

\section{2. 結果と考察}

\section{1 醳素の部分精製と選択}

Fig. 2 に酵素の精製結果を示している. 第 1 ピークがセルラー ゼ活性画分（PEAK I と仮称）であり，第 2 ピークが $\beta$ 
Table 1 Comparison of partially purified cellulase activities toward various substrates.

\begin{tabular}{cccc}
\hline & $\begin{array}{c}\text { MCC } \\
\text { hydrolytic } \\
\text { activity } \\
(\mathrm{mg} \mathrm{tot} \mathrm{a} \mathrm{g} / \mathrm{m} / \mathrm{min})\end{array}$ & $\begin{array}{c}\text { CMC } \\
\text { hydrolytic } \\
\text { activity } \\
\text { sugar reducing } \\
\text { sugar/g/min) }\end{array}$ & $\begin{array}{c}p \text {-NPG } \\
\text { hydrolytic } \\
\text { activity } \\
(\mathrm{mg} p \text {-NP/g/ } \\
\mathrm{min})\end{array}$ \\
\hline PEAK I & 3.1 & $2.8 \times 10^{2}$ & $1.0 \times 10^{-2}$ \\
PEAK II & 3.9 & $1.6 \times 10^{3}$ & $6.9 \times 10^{2}$ \\
Crude cellulase & 4.1 & $5.9 \times 10^{2}$ & $5.5 \times 10$ \\
\hline
\end{tabular}

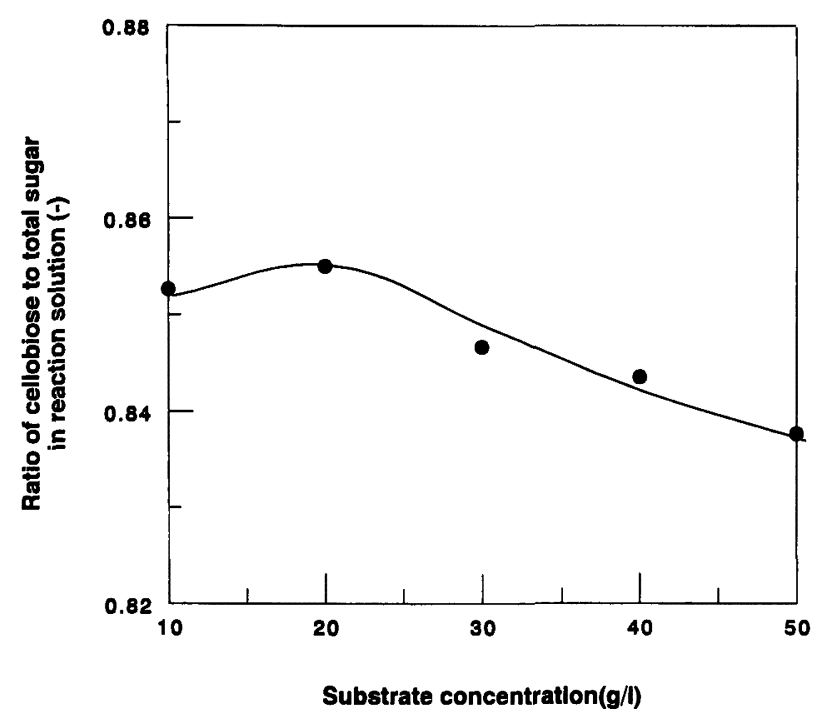

Fig. 3 Effect of substrate concentrations on productivity of cellobiose from MCC under batch reaction

glucosidase 活性画分 (PEAK II と仮称) である. Table 1 に粗酵 素および得られた 2 活性画分の比活性を示している. PEAK I と

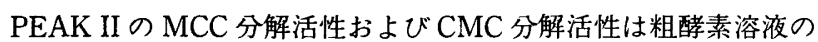
値と殆ど変わらず，活性の著しい減少は見られない，一方，粗酵 素溶液の活性の值を基準として比較すると， $\beta$-glucosidase 活性 に関してはPEAK I では 1/5,500 倍, PEAK II では 12 倍となっ ており， $\beta$-glucosidase 活性成分は PEAK I から殆ど除去されて いると考之られる.この結果は粗酵素から容易に $\beta$-glucosidase 活性を除去できることを示しており，PEAK I は本研究で使用で きることが明らかとなった。

\section{2 最適反応条件でのセロビオース生産（回分反応）}

最適なセロビオース生産条件を決定するため反応液中の基質浱 度および酵素濃度を検討した. 酵素濃度 $1.0 \mathrm{~g} / l$ の下でセロビオ 一ス生産性に対する基質濃度の影響を検討した絬果を Fig. 3 に 示した. 反応溶液中の全糖量に対するセロビオース量の割合が大 きい方がセロビオース生産性が高いと考えられる. 実験結果より セロビオース生産性の点ではそれほど差は大きくはないが, 効率 面を考慮すると最適基質濃度は $20 \mathrm{~g} / l$ 付近にあると考之られる. 一方, MCC 濃度を $20 \mathrm{~g} / l$ の下で酵素濃度を変化させてセロビオ 一ス生産性を検討した結果が Fig. 4 である.酵素濃度が $3.0 \mathrm{~g} / \mathrm{l}$ 以上では生成セロビオース濃度はほとんど増大していないことが 明らかとなった. 以上から, Fig. 5 に先に示した最適条件 $(20.0 \mathrm{~g} /$ $l \mathrm{MCC}, 3.0 \mathrm{~g} / l$ PEAK I) でのセロビオース生産の経時変化を 示した. セロビオース濃度は反応 15 時間で $3.9 \mathrm{~g} / l$ に達した後, 30 時間目位まではほほ一定值を保ち，その後は徐々に低下して行 った。しかしながら，グルコース浱度は反応開始時より次第に増 大している，セロビオースを高濃度で回収するためには, 反応時

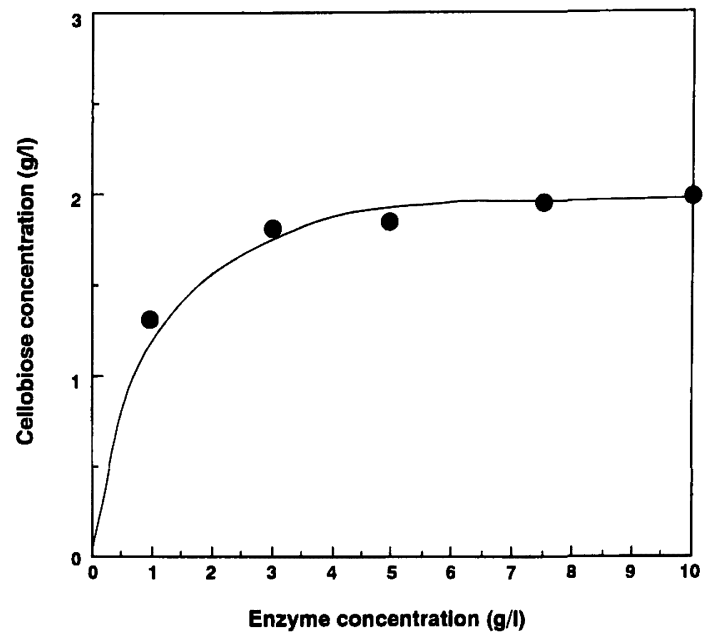

Fig. 4 Effect of enzyme concentrations on productivity of cellobiose from MCC under batch reaction

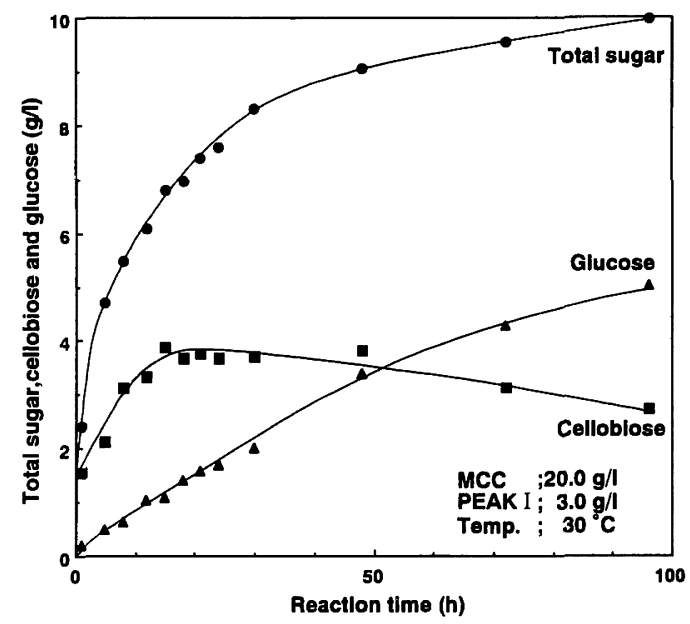

Fig. 5 Time course of MCC hydrolysis under the optimal reaction conditions. The reaction was performed with batch method

間を 15 30 時間程度とするのが適当であり, 反応 15 時間目のセ ロビオース漂度/グルコース濃度の值は 3.6 であった。

\subsection{MCC の連続供給によるセロビオース生産（連続反応）}

Reactor 内の反応初期 MCC 濃度を $50.0 \mathrm{~g} / l$ とし, PEAK I 竖 度を $3.0 \mathrm{~g} / l$ として連続分解反応を行ったときの結果を Fig. 6 に 示している. MCC reservoirより MCC 照濁液 $(55.0 \mathrm{~g} / l)$ を 12.8 $\mathrm{mg} \mathrm{MCC} / \mathrm{h}$ で供給し, Reactor 内での滞留時間は 21.5 時間とし た. 反応開始後, 一時的に生成糖濃度が高くなっているのは初期 基質浱度が高いことと，七ルラーゼにより基質 MCC 中に存在す る比較的分解されやすい部分 (非晶質部分) が専ら分解されるこ とに起因している. 反応時間が長くなるに従い反応槽中の MCC の非晶質部分の割合は徐々に減少し, それに伴って分解速度が低 下する，基質 MCC は分解量に見合うだけの一定量しか供給して いないので, やがて分解速度が一定となり, 生成物の槽内濃度が 一定 (定常状態)となると考えられる. Reactor 内のセロビオース 濃度は反応 168 時間目付近以降ほほ一定（約 $3.5 \sim 3.0 \mathrm{~g} / l$ ) とな $\eta$, 定常状態が得られた時の Reactor 内の MCC 残存濃度は 35 $\mathrm{g} / l$ であった. 槽内セロビオース濃度がほぼ一定となっている反 応時間 168 時間目から 576 時間目までの定常状態の間に添加した $\mathrm{MCC}$ 量は $5.2 \mathrm{~g}$ であり, セロビオースは $3.1 \mathrm{~g}$ 生産された. MCC 


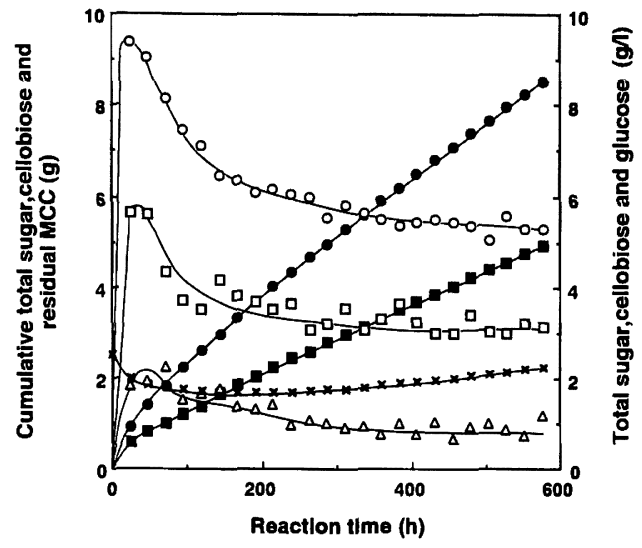

Fig. 6 Time course of a continuous MCC hydrolysis. Cumulative total $\operatorname{sugar}(\mathrm{g}), \mathbf{\square}$; Cumulative cellobiose $(\mathrm{g}), \times$; Residual MCC in reactor $(\mathrm{g}), \bigcirc$; Total sugar in reactor $(\mathrm{g} / \mathrm{l}), \square$; Cellobiose in reactor $(\mathrm{g} / l), \triangle$; Glucose in reactor $(\mathrm{g} / \mathrm{l})$

供給全量と Reactor 内残存量を考慮すれば MCC 分解率は $90 \%$ であり，セロビオース量/(セロビオース量+グルコース量）の值 は75\%であった. MCC はPEAKIにより完全に加水分解される ことが確かめられていることより， MCC 分解率が $90 \%$ であった のは MCC 供給速度が MCC 分解速度より大きかったことによる と推察される.この実験の場合, MCC 供給速度を $11.5 \mathrm{mg} \mathrm{MCC/}$ $\mathrm{h}$ とすれば $100 \%$ の分解率が得られるはずである. Reactor 内の 残存基質量が徐々に増大しているのは主に基質供給過剩に起因し ている.

\section{4 既往の実験結果との比較}

我々の実験に類似した研究報告は見当たらないので, Ina and Kinoshita (1993) の実験結果と比較検討した. 既往の研究では基 質として KC-flock を用い, 基質は間欠供給 $(5.0 \mathrm{~g}$ を 3 回に分け て供給)された。我々の場合は連続供給を行い, 供給された MCC

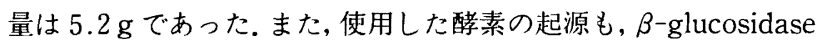
活性を除去するための分画方法も異なっている。しかしながら， 得られた部分精製酵素（Enzyme A) は低活性ではあるが $\beta$ glucosidase 活性を含んでおり, 我々の使用したPEAK Iも低活 性の $\beta$-glucosidase 活性を含んでいるので, Enzyme A で行われ た実験結果と比較した. 本実験で得られる MCC 分解萍は $90 \%$ で あり, 既往の研究結果のそれは $81 \%$ となっており,よく似た結果 である.しかしながら, 回収した反応液中のセロビオース/グルコ 一スの値は本実験では 3.0 であるのに対し, 既往の実験では 0.5 となっており，明らかに本実験の場合が高くなっている，同様に， セロビオース含有率 (=セロビオース最/(セロビオース量+グル コース量)) は本実験の場合の $75 \%$ に対して, 既往の実験では 32 \%となっており, 本実験の場合の方がかなり高くなっている.七 ロビオース収率 (=回収セロビオース量/供給基質量）もまた, 本 実験の場合の $60 \%$ に対して，既往の実験では $23 \%$ となっており， 本実験の場合の方がかな高くなっている. 一方, 既往の実験で
用いられた Enzyme B ( $\beta$-glucosidase 活性を含まない)の場合に は, セロビオース/グルコースの值が, 本実験の場合に比べて 3 倍 程高くなっているのは当然のことである.しかしながら, セロビ オース収率は殆ど同じであった。

即ち, 基質の連続供給法では必ずしも $\beta$-glucosidase 活性を完 全に除去しなくても，高収率でセロビオースを生産することが可 能であることが明らかとなった。

\section{結言}

Trichoderma viride 起源のセルラーゼ標品より1段階のカラム クロマトグラフィーで、ほぼ完全に $\beta$-glucosidase 活性の除去さ れたセルラーゼ活性画分(PEAK I) が得られた. PEAK I は MCC を完全に加水分解できることを確かめたのち，MCCの連続加水 分解実験に供した. PEAK I $(3.0 \mathrm{~g} / l)$ を槽内に保持できる反応 槽 (Reactor) 内へ, MCC 㗭濁液 $(55.0 \mathrm{~g} / l)$ を連続的に供給 $(12.8$ $\mathrm{mg} \mathrm{MCC} / \mathrm{h}$ ) しながら, MCCの加水分解を行った. その結果, 反応 168 - 576 時間の間で定常状態が得られ, セロビオース濃度は 約 3.5 3.0 g/l, セロビオース含有率は $75 \%$, およびセロビオー ス/グルコースは 3.0 であった. その上, セロビオース収率は $60 \%$ であった.これらの値は, Ina and Kinoshita (1993) の実験 (Enzyme A の場合) の值と比較して (実験条件が異なるので正確 には比較できないが)，いずれも相当に高い值である，本実験にお けるMCCの連続加水分解系は生成物が連続的に反応槽外に取り 出されるのでセロビオースのグルコースへの分解が抑えられるこ と, および, 反応中の酵素の失活がほとんどないので, 酵素の損 失が少ないことなどの利点を有する.

\section{Literature cited}

Homma, T., M. Fujii, U. Titus, E. D. Bakar and M. Taniguchi; "Fractionation of the $\beta$-Glucosidase Component from Cellulase by Cellulose Columns and Production of Cellobiose by the Residual Enzymes," J. Chem. Eng. Japan, 25, 288-293 (1992)

Homma, T, M. Fujii. J. Mori, T. Kawakami, K. Kuroda and M.Taniguchi; "Production of Cellobiose by Enzymatic Hydrolysis: Removal of $\beta$-Glucosidase from Cellulase by Affinity Precipitation Using Chitosan," Biotechnol. Bioeng., 41, 405-410 (1993)

Ina, H. and S. Kinoshita; "Production of Cellobiose by an Ultra-Filter Membrane Reactor," J. Ferment. Bioeng., 76, 340-341 (1993)

Ishikura, S. ; "Tourui, tou-arukoru nado (1)," Gekkan fuudo kemikaru, No. 11, 12-19 (1992)

Okada, G and Y. Tanaka; "Cellulase-Enzymatic Degradation Mechanisms of Native Cellulose," J. Jpn. Soc. Starch Sci., 35, 253-277 (1988)

Ooshima, H., R. Sugiyama and Y. Harano ; "Production of Cellobiose by Enzymatic Hydrolysis of Pretreated Bagasse," Proceedings of CJCHE., 91, p. 553-559, Tianjin, China (1991)

Sakai, S. ; "Origotou no kaihatsu no genjou," Gekkan fuudo kemikaru, No. 4, 81-88 (1995)

Taniguchi, H.; "Production and Properties of Cellobiose," Nippon Nogeikagaku Kaishi, 63, 1133-1135 (1989) 


\title{
Efficient Continuous Production of Cellobiose by Hydrolysis of Crystalline Cellulose with Cellulase
}

\author{
MITSUO TANAKA, ATSUSHI FUJIMOTO and RYOJ MITSUI
}

\author{
Department of Biochemistry, Faculty of Science, Okayama University of Science, Okayama 700-0005
}

Key words: cellobiose production, cellulase, continuous hydrolysis, crystalline cellulose.

Cellulase preparation derived from Trichoderma viride was chromatographed in one step by a column. The fraction which had cellulase activity (PEAK I) had little $\beta$-glucosidase activity. PEAK I was used for continuous hydrolysis of MCC. Holding PEAK I $(3.0 \mathrm{~g} / l)$ in a reactor and supplying MCC suspension $(12.8 \mathrm{mg} / \mathrm{h})$ into a reactor continuously, the hydrolysis of MCC in a reactor was performed. As the result, during the steady state from $168 \mathrm{~h}$ to $576 \mathrm{~h}$, the concentration of cellobiose in a reactor is about 3.5 to $3.0 \mathrm{~g} / \mathrm{l}$, the content ratio of cellobiose in reaction solution collected, $75 \%$, and the ratio of cellobiose to glucose, 3.0. Moreover, the yield of cellobiose is $60 \%$. All these values are considerably high, compared with the experimental value in the previous paper. The system of continuous MCC hydrolysis in this paper has two main merits, in that the hydrolysis of cellobiose to glucose is prevented because the reaction products are taken out of the reactor continuously, and the loss of enzyme is low because inactivation of the enzyme hardly occurrs during the reaction. 